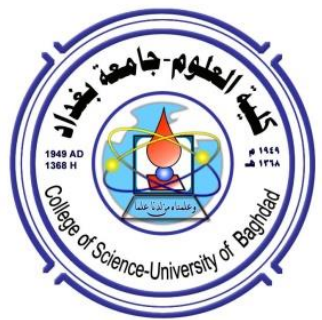

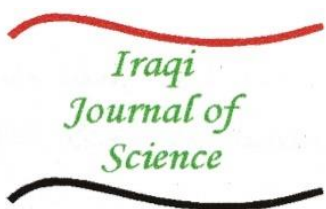

ISSN: 0067-2904

\title{
Cu-ZnO Nanostructures Synthesis and Characterization
}

\author{
Saif T. Abdulredha, Nadia A. Abdulrahman* \\ Department of Chemistry, College of Science, University of Baghdad, Baghdad, Iraq
}

Received: 17/4/2020 Accepted: 19/6/2020

\begin{abstract}
$5 \mathrm{wt} \%$ copper doped zinc oxide $(\mathrm{Cu}-\mathrm{ZnO})$ nanostructures were prepared via the hydrothermal technique at different temperatures of $70,100,130,160$ and $190^{\circ} \mathrm{C}$. UV spectroscopy, FE-SEM microscopy, XRD crystallography, and EDS measurements were used for nanostructure characterization. UV spectroscopy indicated a red shift for the absorption peaks, and hence a blue shift for the energy gap values, as temperature increased from 70 to $190^{\circ} \mathrm{C}$. FE-SEM microscopy showed an increase in the average lengths and diameters of the nanostructures following a similar increase in temperature. XRD crystallography indicated decent structural patterns for $\mathrm{Cu}-\mathrm{ZnO}$ nanostructures with an increase in crystallite size upon temperature increase. Interestingly, three unprecedented extra indices appeared in the structural pattern at $190^{\circ} \mathrm{C}$, which might indicate a configuration of hexagonal crystallite with three extra planes. EDS measurements indicated the sole presence of $\mathrm{Cu}, \mathrm{Zn}$ and $\mathrm{O}$.
\end{abstract}

Keywords: Nanostructures, Nanorods, Copper doped, $\mathrm{Cu}-\mathrm{ZnO}$ nanostructures, Semiconductors, Hydrothermal.

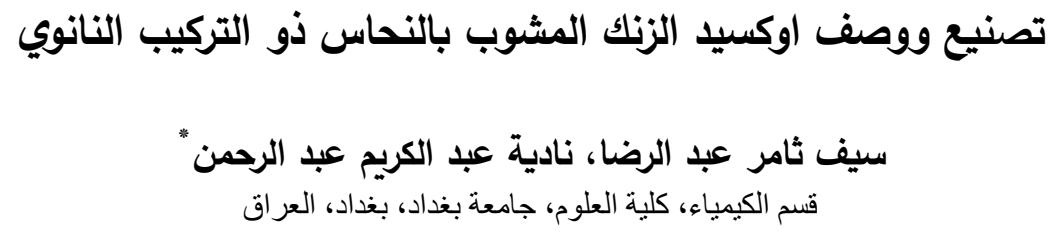

الخلاصها

تم تصنيع المركبات النانوية لأوكسيد الزنكك المشوب بالنحاس بنسبة وزنية 5\% بواسطة طريقة تقنية

الهايدروثيرمل وبدرجات حرارية مختلفة (160،130،100،70و 190 مؤي ) .لتحديد مواصفات المبات المتراكبات

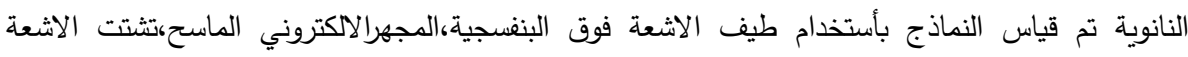

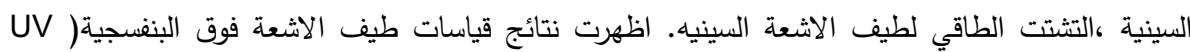

(spectroscopy

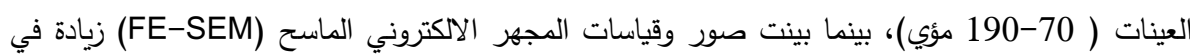

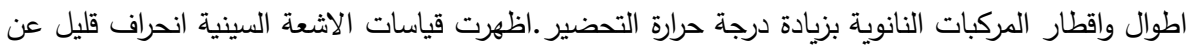

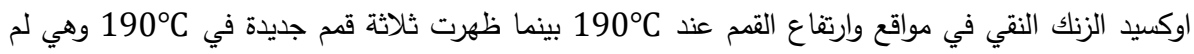

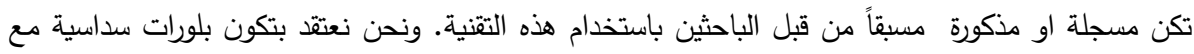

ثلاث اوجه جديدة، وقد اشارت قياسات التشتت الطاقي لطيف الاشعة السينية(EDS) لوجود O,Zn,Cu فقط.

"Email: nadiaabdulrahman73@yahoo.com 


\section{Introduction}

Zinc oxide is an inorganic white powder with the chemical formula of $\mathrm{ZnO}$ and crystallite configuration of either wurtzite hexagonal or zincblende cubic. Wurtzite hexagonal is the most common configuration since it is more stable, whilst zincblende is less common since it requires certain conditions to be configured. In either way, zinc and oxygen are spatially arranged as tetrahedral centres [1-5].As a II-VI semiconductor with wide band gap energy of $3.37 \mathrm{eV}$ and large exciton binding energy of $60 \mathrm{meV}, \mathrm{ZnO}$ is being used for decades for various optical, electrical, and mechanical applications. These include piezoelectric devices, light emitting diodes (LEDs), gas sensors, photocatalysts in solar cells, corrosion inhibitors, and antibacterial biosensors [6-10]. Apart from zinicit, which is a zinc oxide that is naturally found with hexagonal configuration, several methods are being used to produce $\mathrm{ZnO}$ as either bulk particles, e.g. via French process, indirect method, and wet chemical process, or as nanostructures, e.g. via hydrothermal technique, sol-gel method, laser ablation, etc. [2-4, 6-12]. In the present work, we used the hydrothermal technique since it requires low temperature, low expenses, and short time, being environmentally clean and nontoxic, with key parameters that could be easily tuned and controlled [2, 3, 12]. As we already suggested in our previous work, defects may have great potentials to enhance optical, electrical, mechanical, and chemical properties [3]. Nevertheless, defects do not only genuinely occur, but could also be deliberately induced via doping in order to modify the crystallite structure. We and others believe that the latter approach would have useful potentials [13-18]. Doping might modify the crystallite tetrahedral configuration of $\mathrm{ZnO}$ and, hence, affect its entire corresponding properties. For example, if $\mathrm{ZnO}$ is doped with a transitional element, such as copper, nickel, or cobalt, its luminescence capacities would be enhanced and, hence, it could be used in bioimaging for sensitive detection. Another example can be the doping of $\mathrm{ZnO}$ with copper, where conductivity would be increased since copper is a highly conductive metal and, hence, it could be altered from a semiconductor to a conductor [11, 12, 19-24]. In this study, we doped $5 \mathrm{wt} \%$ copper within $\mathrm{ZnO}$ crystallite structure using the hydrothermal technique at different temperatures of $70,100,130,160$ and $190^{\circ} \mathrm{C}$. The doped structure was then characterized using UV spectroscopy, FE-SEM microscopy, XRD crystallography, and EDS measurements. We aimed to show the effects of temperature variation on the shapes and sizes of $\mathrm{Cu}$ $\mathrm{ZnO}$ nanostructures.

\section{Experimental Part \\ Methodology}

$\mathrm{Cu}$-doped $\mathrm{ZnO}(\mathrm{Cu}-\mathrm{ZnO})$ nanostructures were prepared at a range of temperature of $70,100,130$, 160 and $190^{\circ} \mathrm{C}$ using $1 \mathrm{M}$ zinc acetatedihydrate $\left(\mathrm{Zn}\left(\mathrm{CH}_{3} \mathrm{COO}\right)_{2} .2 \mathrm{H}_{2} \mathrm{O}, \mathrm{M} . \mathrm{W}=219.5 \mathrm{~g}^{\mathrm{mol}}{ }^{-1}\right.$, BDH Chemicals), 5M sodium hydroxide ( $\mathrm{NaOH}, \mathrm{MW}=40.99$, 98\%, ALPHA) and 5\% copper acetatedihydrate $\left(\mathrm{Cu}\left(\mathrm{CH}_{3} \mathrm{COO}\right)_{2} \cdot 2 \mathrm{H}_{2} \mathrm{O}, \mathrm{M} . \mathrm{W}=217.5 \mathrm{~g} \cdot \mathrm{mol}^{-1}\right.$, Science Company). All solutions were prepared using $95 \%$ methanol $\left(\mathrm{CH}_{3} \mathrm{OH}, \mathrm{MW}=32.04 \mathrm{~g} \cdot \mathrm{mol}^{-1}\right.$, Scharlau $)$ as a solvent. The hydrothermal technique was used in order to maintain high temperature and pressure via a Teflon-lined stainless steel autoclave system (polypropylene liner PPL). The reactor with a curled heater was encircled in order to maintain equal and continuous heat distribution during the reaction (Figure-1). 5wt\% of $\mathrm{Cu}\left(\mathrm{CH}_{3} \mathrm{COO}\right)_{2} \cdot 2 \mathrm{H}_{2} \mathrm{O}$ was dissolved in $10 \mathrm{ml}$ of $1 \mathrm{M} \mathrm{Zn}\left(\mathrm{CH}_{3} \mathrm{COO}\right)_{2} \cdot 2 \mathrm{H}_{2} \mathrm{O}$ and well mixed via magnetic stirring for five minutes before mixing with $40 \mathrm{ml}$ of $5 \mathrm{M} \mathrm{NaOH}$ inside the reactor. The reactor was then sealed and left for at least $10 \mathrm{hrs}$ at the above-mentioned temperatures. The mixture was then decanted in a $100 \mathrm{ml}$ beaker and washed several times with distilled water until reaching a $\mathrm{pH}$ value of 7. Then, a final washing step with ethanol was performed for at least three times. The nanostructures powder was then separated and dried under $100^{\circ} \mathrm{C}$ for $2 \mathrm{hrs}$.

\section{Instrumental Tests}

The synthesized samples were characterized for their structure by x-ray diffraction (SHIMADZU 6000/X-Ray / Japan.) with $\mathrm{Cu} \mathrm{K \alpha}$ radiation. The optical band gap ( $\left.\mathrm{E}_{\mathrm{g}}\right)$ was estimated via the UV-VisNIR diffuse reflectance spectroscopic (SHIMADZU 1800/ Double Beam/ Japan) studies in a wavelength range of $200 \mathrm{~nm}$ to $1100 \mathrm{~nm}$. The samples were used in the form of powder, while FESEM (S-4160/Hitachi/ Japan) was used as the reference for images. The elemental composition of the $\mathrm{ZnO}$ nanostructures was determined by using EDS S-4160/Hitachi/Japan. 


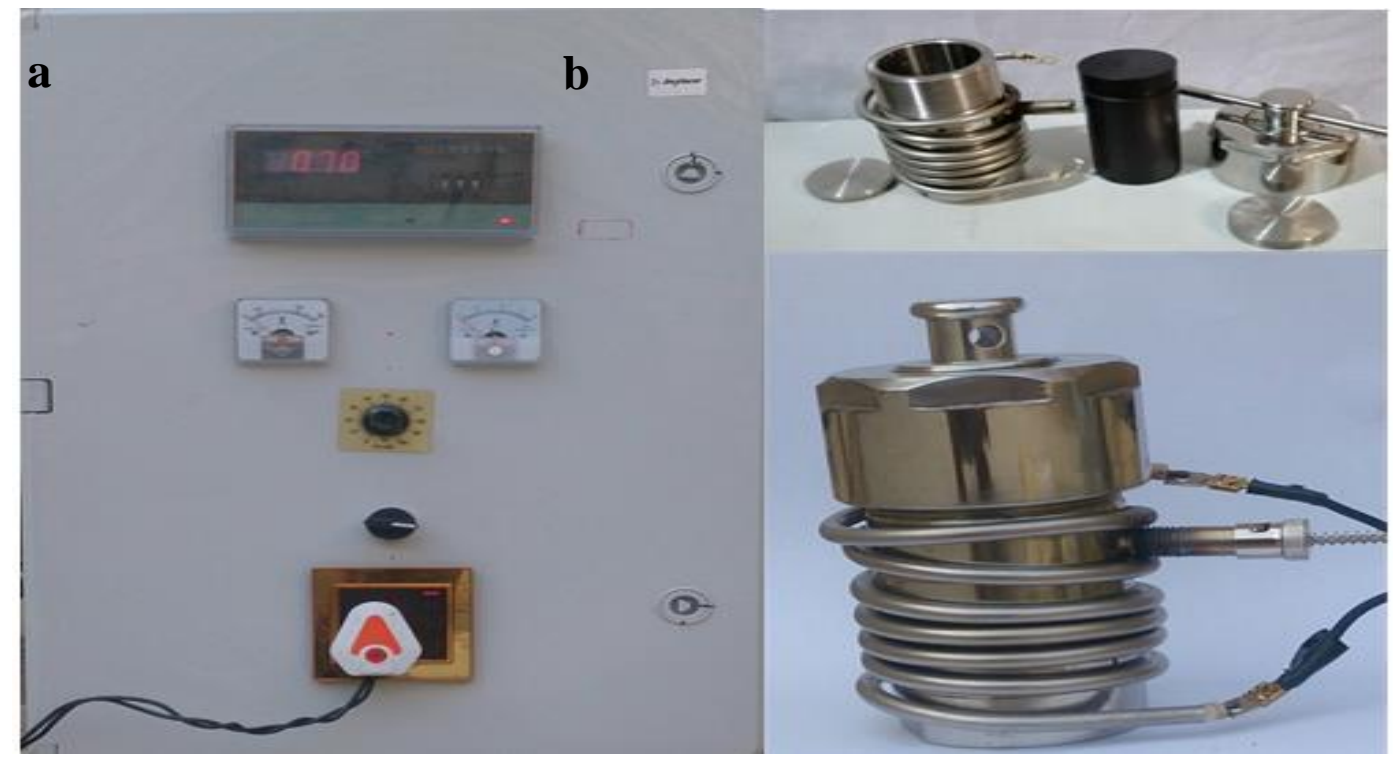

Figure 1- Hydrothermal system consisting of two main parts: (a) Temperature controller unit.(b) Reaction unit.

\section{Results and Discussion \\ XRD crystallography and EDS measurements}

XRD crystallography indicated the purity and well crystallinity of $\mathrm{Cu}-\mathrm{ZnO}$ and the undoped $\mathrm{ZnO}$ nanostructures with hexagonal wurtzite crystallites, as they all matched the structural pattern for pure zinc oxide described by JCPDS (Joint Committee on Powder Diffraction Standards) card no 01-0790205. At two different temperatures of 70 and $190{ }^{\circ} \mathrm{C}$, XRD crystallography showed intense diffraction angles for the indices of 100, 002, 101, 102, 110, 103, 200,112, 201, 004, and 202 at a range of diffraction angles of 10 to 80 degree (Figure-2). Crystallite size was estimated by applying Scherrer equation, as previously described [3]. As demonstrated in Figure-2, crystallite size of $\mathrm{ZnO}$ nanostructures was increased from 19.44 to $30.55 \mathrm{~nm}$ whereas that of undoped $\mathrm{ZnO}$ nanostructures was increased from $21.75 \mathrm{~nm}$ to $37.05 \mathrm{~nm}$ as temperature was increased from $70^{\circ} \mathrm{C}$ to $190{ }^{\circ} \mathrm{C}$, respectively. Also, peak intensities for $\mathrm{Cu}-\mathrm{ZnO}$ nanostructures were found to be reduced in comparison to those for undoped $\mathrm{ZnO}$ nanostructures, which obviously indicated a reduction in crystallite size [3]. Based on these observations, the crystallite size of $\mathrm{Cu}-\mathrm{ZnO}$ nanostructures is considered to be decreased in comparison to that of undoped $\mathrm{ZnO}$ nanostructures, which is expected and in line with results reported by other studies, since doping with copper implies that the zinc atom would be replaced by the much smaller atom of copper [24-27]. Interestingly, at $190^{\circ} \mathrm{C}, \mathrm{Cu}-\mathrm{ZnO}$ diffraction pattern showed three new peaks at $43.46,50.62$, and $74.30^{\circ}$, which, as far of our knowledge, have not been previously reported. This might indicate the formation of hexagonal crystallites with three extra planes (Figure-2). In fact, one might argue that these extra peaks could reflect crystallite impurity, but EDS measurements indicated the sole existence of $\mathrm{Cu}, \mathrm{O}$, and $\mathrm{Zn}$ in $\mathrm{Cu}-\mathrm{ZnO}$ nanostructures and $\mathrm{O}$ and $\mathrm{Zn}$ in the undoped $\mathrm{ZnO}$ nanostructures (Figure-3). At this stage, it is not possible to define the exact configurations of these extra planes neither the exact parameters which might affect their growth. It is even not possible to define the appearance of yet more planes, or how these extra planes have modified the spatial configuration of the crystallites, and how their optical, mechanical, electrical, and chemical properties would be changed accordingly. It is a matter of interest to resolve these issues in future works. 

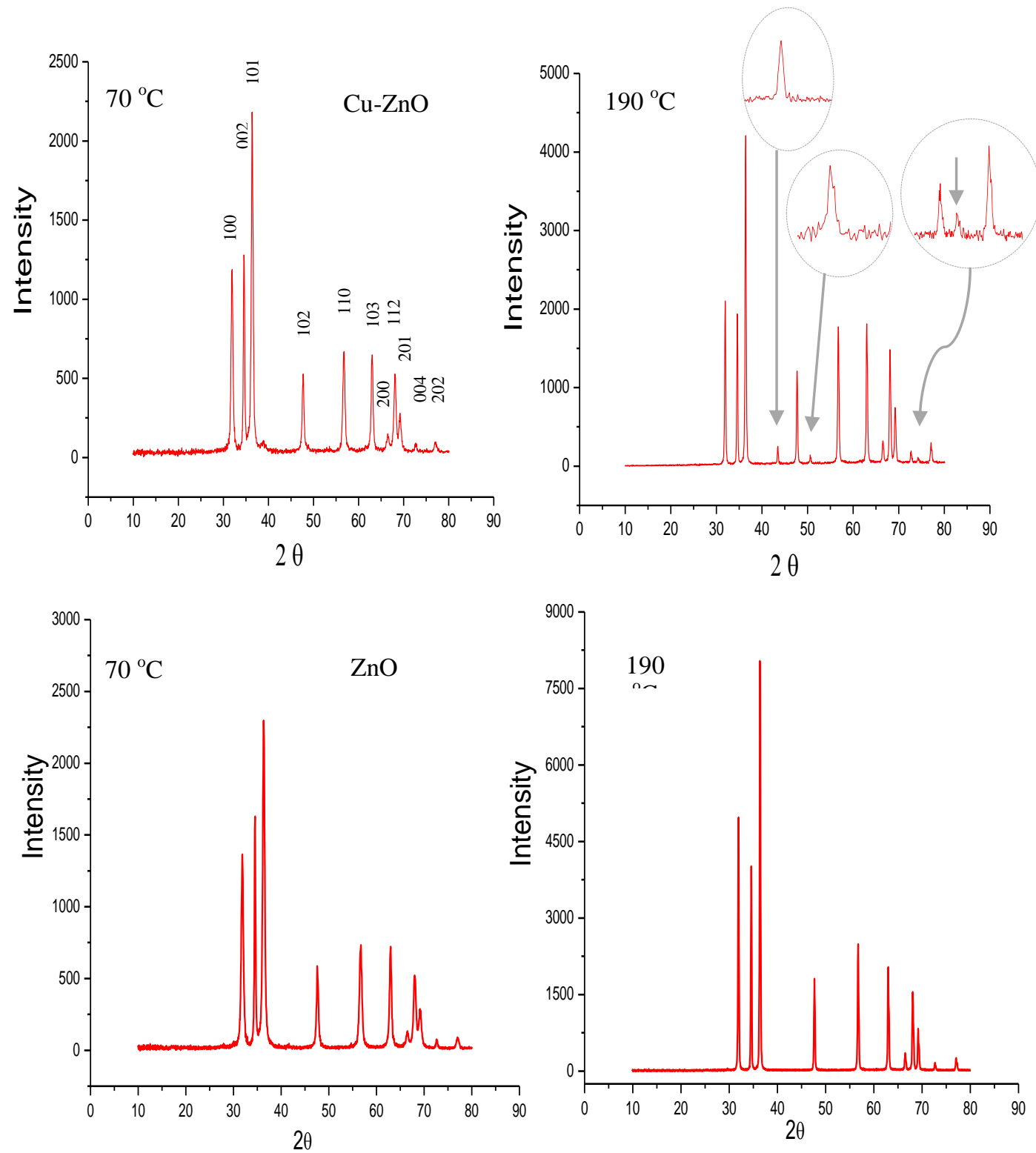

Figure 2- $\mathrm{XRD}$ crystallography for $\mathrm{Cu}-\mathrm{ZnO}$ nanostructures (top) and undoped $\mathrm{ZnO}$ nanostructures (bottom) at temperatures of 70 and $190{ }^{\circ} \mathrm{C}$. The patterns indicate a wurtzite hexagonal configuration which perfectly match the pattern given by the Reference code:01-079-0205. At $190^{\circ} \mathrm{C}$ (top), we emphasized the three extra peaks at $43.46,50.62$ and $74.30^{\circ}$ via three inset spectra. 

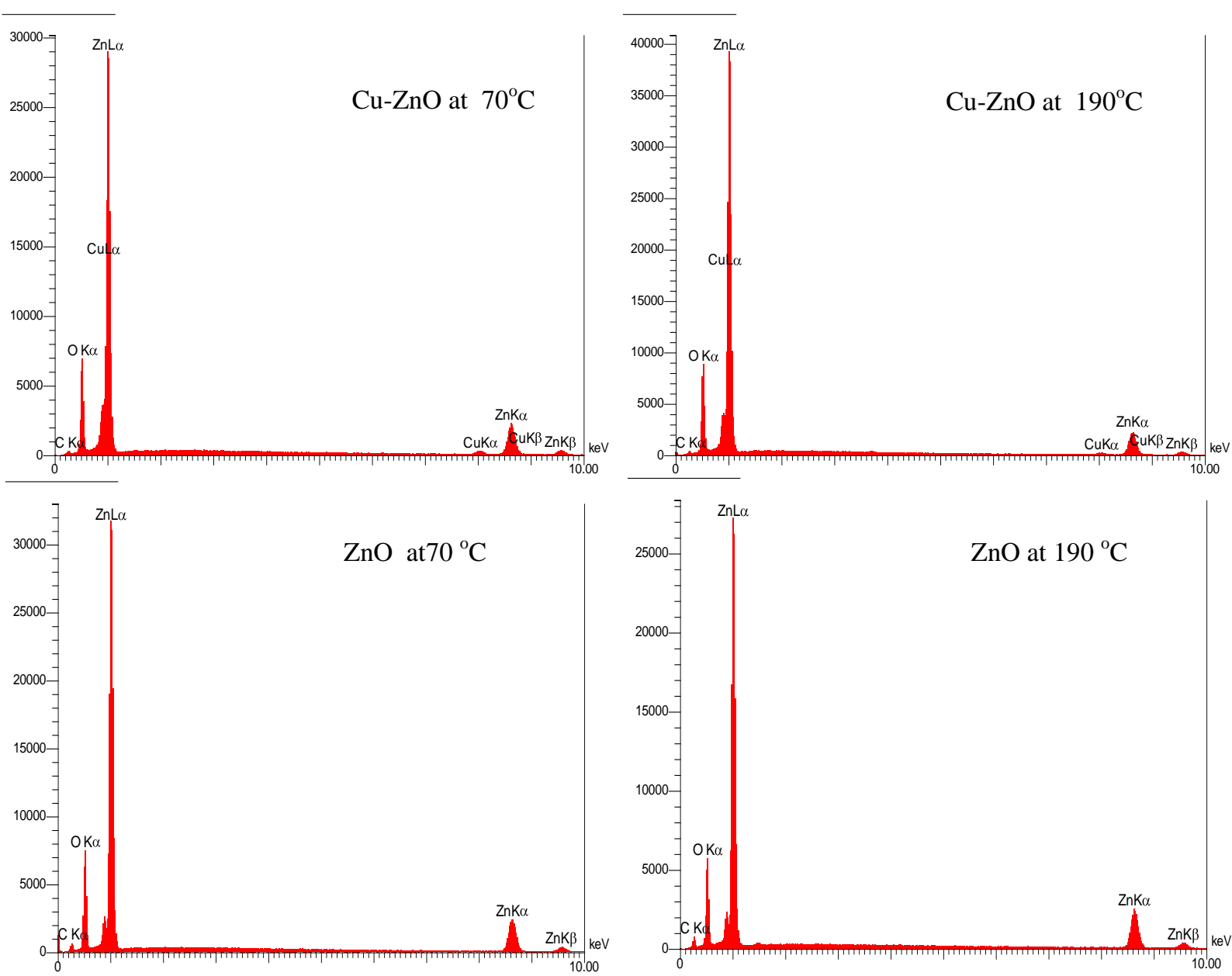

Figure 3-EDS spectra for $\mathrm{Cu}-\mathrm{ZnO}$ nanostructures (top) and undoped $\mathrm{ZnO}$ (bottom) synthesized via the hydrothermal technique at 70 and $190{ }^{\circ} \mathrm{C}$.

\section{FE-SEM microscopy}

FE-SEM microscopy showed an obvious temperature impact on the growth and morphology of the $\mathrm{Cu}-\mathrm{ZnO}$ nanostructures. This is consistent with our previous work and that of others [28-31]. We believe that the growth and, hence, the change of particle size and shape, should be expected as temperature or incubation time, or maybe both, are increased. This is because of a natural phenomenon called Ostwald Ripening, in which small particles with small surfaces, and, hence, high kinetic energy, start to deposit themselves on the surfaces of the larger-sized particles then diffuse within these particles to end up with yet larger ones. In other words, this phenomenon occurs to stabilize the small particles [2, 3, 32-34]. Figures-4 and 5 show FE-SEM images for $\mathrm{Cu}-\mathrm{ZnO}$ nanostructures and the undoped $\mathrm{ZnO}$ nanostructures synthesized at two different temperatures of 70 and $190^{\circ} \mathrm{C}$, respectively, and at three different scales bars of $200 \mathrm{~nm}, 500 \mathrm{~nm}$ and $1 \mu \mathrm{m}$. In Figure-4(a,b,c), the average size of $\mathrm{Cu}-\mathrm{ZnO}$ nanostructures was found to be $20-50 \mathrm{~nm}$, with polygonal dots-like shapes. In Figure-4(d,e,f), the average size of the undoped $\mathrm{ZnO}$ nanostructures was found to be $150-200 \mathrm{~nm}$, with rod like shapes. The average length was $150-200 \mathrm{~nm}$ and the average diameter was 10-20 nm. In Figure $5(\mathrm{a}, \mathrm{b}, \mathrm{c})$, the average size of $\mathrm{Cu}-\mathrm{ZnO}$ nanostructures was found to be $200-300 \mathrm{~nm}$ with a variation from trigonal to hexagonal rod-like shapes. In Figure-5(d,e,f), the average size of the undoped $\mathrm{ZnO}$ nanostructures was found to be $>2 \mu \mathrm{m}$ (the average length was $200-2000 \mathrm{~nm}$ and the average diameter was $100-1000 \mathrm{~nm}$ ), with tetrahedral-like shapes. In general, Figures- 4 and 5 show that the average size of $\mathrm{Cu}-\mathrm{ZnO}$ nanostructures is much smaller than that of the undped $\mathrm{ZnO}$ nanostructures, which is 
in line with results from earlier works [35-37]. These results are also in line with the results of our XRD crystallography, which showed smaller crystallite size of $\mathrm{Cu}-\mathrm{ZnO}$ nanostructures in comparison to that of the undoped $\mathrm{ZnO}$ nanostructures (Table-1).

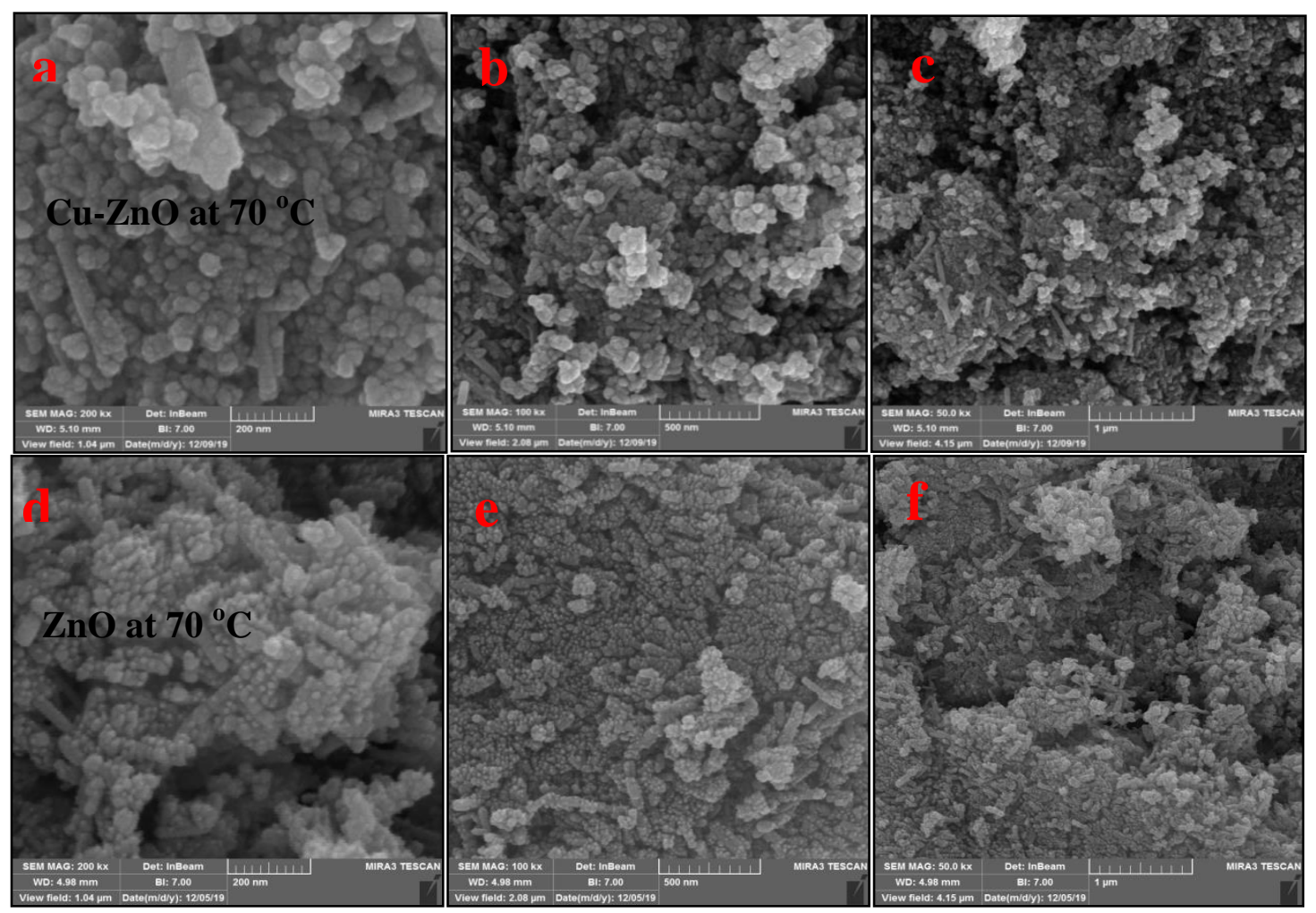

Figure 4- FE-SEM images for $\mathrm{Cu}-\mathrm{ZnO}$ and undoped $\mathrm{ZnO}$ nanostructures synthesized at $70{ }^{\circ} \mathrm{C}$ using Teflon lined stainless steel autoclave in a hydrothermal system. Images are shown in three scales, namely: a. $200 \mathrm{~nm}$, b. $500 \mathrm{~nm}$ and c. $1 \mu \mathrm{m}$ for $\mathrm{Cu}-\mathrm{ZnO}$ nanostructures and d. $200 \mathrm{~nm}$, e. $500 \mathrm{~nm}$ and f. $1 \mu \mathrm{m}$ for undoped $\mathrm{ZnO}$ nanostructures.

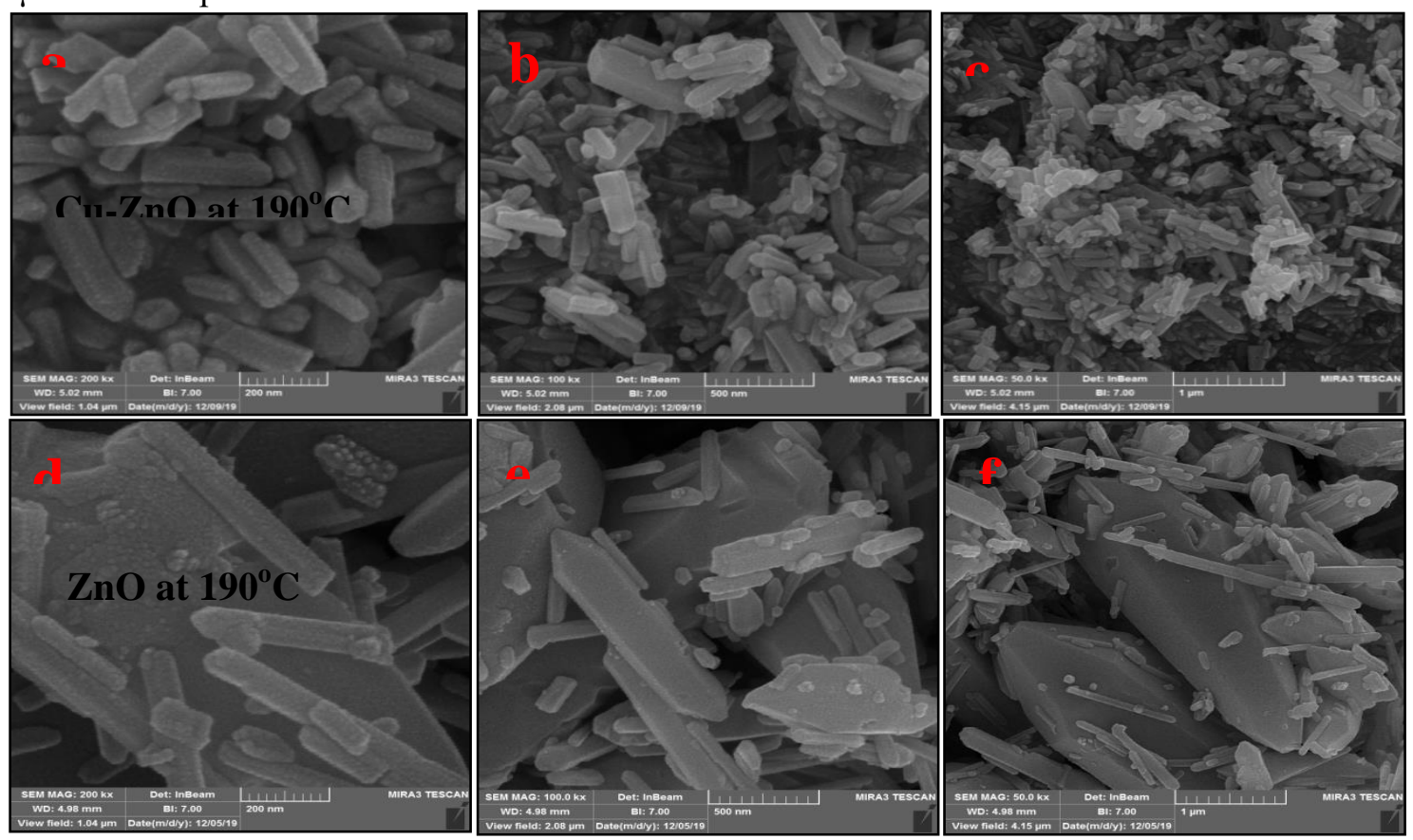

Figure 5-FE-SEM images for $\mathrm{Cu}-\mathrm{ZnO}$ and undoped $\mathrm{ZnO}$ nanostructures synthesized at $190{ }^{\circ} \mathrm{C}$ using Teflon lined stainless steel autoclave in a hydrothermal system. Images are shown in three scales, namely: a. $200 \mathrm{~nm}$, b. $500 \mathrm{~nm}$ and c. $1 \mu \mathrm{m}$ for $\mathrm{Cu}-\mathrm{ZnO}$ nanostructures and d. $200 \mathrm{~nm}$, e. $500 \mathrm{~nm}$ and f. $1 \mu \mathrm{m}$ for undoped $\mathrm{ZnO}$ nanostructures. 
Table 1- Particle and crystallite sizes for $\mathrm{Cu}-\mathrm{ZnO}$ and undoped $\mathrm{ZnO}$ nanostructures determined by SEM microscopy and XRD crystallography.

\begin{tabular}{||c|c|c|c|c||}
\hline Nanostructures & \multicolumn{2}{|c|}{$\mathbf{C u}-\mathbf{Z n O}$} & \multicolumn{2}{|c|}{ ZnO } \\
\hline Temperature & $\mathbf{7 0}^{\circ} \mathbf{C}$ & $\mathbf{1 9 0}{ }^{\circ} \mathbf{C}$ & $\mathbf{7 0}^{\circ} \mathbf{C}$ & $\mathbf{1 9 0}^{\circ} \mathbf{C}$ \\
\hline $\begin{array}{r}\text { Average particle } \\
\text { shape }\end{array}$ & Polygonal dots & Trigonal and hexagonal rods & Rod like shapes & Tetrahedral \\
\hline $\begin{array}{r}\text { Average particle } \\
\text { size via FE-SEM } \\
\text { microscopy }\end{array}$ & $(20-50) \mathrm{nm}$ & $(200-300) \mathrm{nm}$ & $(150-200) \mathrm{nm}$ & $(200-2000) \mathrm{nm}$ \\
\hline $\begin{array}{r}\text { Average crystallite } \\
\text { size via XRD } \\
\text { crystallography }\end{array}$ & $19.44 \mathrm{~nm}$ & $30.55 \mathrm{~nm}$ & $21.75 \mathrm{~nm}$ & $37.05 \mathrm{~nm}$ \\
\hline
\end{tabular}

\section{UV-VIS spectroscopy}

UV-VIS spectra showed absorption peaks at $370,372,373,375$, and $377 \mathrm{~nm}$ for $\mathrm{Cu}-\mathrm{ZnO}$ nanostructures synthesized at five different temperatures of $70,100,130,160$, and $190^{\circ} \mathrm{C}$, respectively (Figure-6a). Following the approach utilized by a previous study [2], the values of band gap energy $\mathrm{E}_{\mathrm{g}}$ were determined. The following equation was applied:

$E_{g}=h C / \lambda$

where $h$ is the Plank constant $=4.135667 \times 10^{-15} \mathrm{eV} . \mathrm{s}, C$ is the speed of light $=3.00 \times 10^{8} \mathrm{~m} / \mathrm{s}$, and $\lambda$ is the maximum wavelength of the absorption peaks in $\mathrm{nm}$.

The values of $\mathrm{E}_{\mathrm{g}}$ were found to be 3.35324, 3.33522, 3.32627, 3.30853, and $3.29098 \mathrm{eV}$ at the temperatures range of $70,100,130,160$, and $190^{\circ} \mathrm{C}$, respectively. For comparison purposes, the results in Figure-6b for the undoped $\mathrm{ZnO}$ nanostructures synthesized using exactly the same parameters showed absorption peaks at $355,360,370,371$, and $373 \mathrm{~nm}$, respectively, at the same temperature values. The values of $\mathrm{E}_{\mathrm{g}}$ were found to be 3.49493, 3.44639, 3.35324, 3.34421 and $3.32627 \mathrm{eV}$, respectively, at the same temperatures range. In general, $\mathrm{E}_{\mathrm{g}}$ values were found to be decreased as the wavelength of absorption peaks and temperatures were increased (Figure- 6c,d and Table-2). This is because particle size naturally tends to be increased as temperature is increased [2, 3]. In Table-2, we show a comparison between the band gap energy values for $\mathrm{Cu}-\mathrm{ZnO}$ nanostructures and those for the undoped $\mathrm{ZnO}$ nanostructures to show the effects of copper doping on the absorption peaks of the wavelengths and, accordingly, on the corresponding band gap energy values. Generally speaking, $\mathrm{Cu}$ $\mathrm{ZnO}$ nanostructures showed higher absorption peaks and, hence, lower band gap energy values in comparison to undoped $\mathrm{ZnO}$ nanostructures, which is in line with the results of other previous works $[35,36,38]$. However, this effect is not due to the particle size as one would expect when examining the UV spectra. As it already mentioned above, XRD crystallography and FE-SEM microscopy showed an obvious reduction in the sizes of $\mathrm{Cu}-\mathrm{ZnO}$ crystallites and nanostructures in comparison with those of undoped $\mathrm{ZnO}$ (Table-1). As such, it is our opinion that the reduction in band gap energy values is due to the free electrons in the outer shells of copper atoms, which are already conductive. We believe that this is a great property to be induced in $\mathrm{ZnO}$ nanostructures, since it would not only reduce the band gap energy values of $\mathrm{ZnO}$ as a semiconductor, but it would also reduce the size of $\mathrm{ZnO}$ nanostructure, i.e. increase its surface area. For this reason, we suggest that copper doping might highly enhance the conductivity, since copper is a conductive metal, and also enhance the optical activity, since it reduces the band gap energy values of $\mathrm{ZnO}$ nanostructures. As such, we expect that $\mathrm{Cu}-\mathrm{ZnO}$ nanostructures would be an inexpensive and powerful candidate that one would choose to 
enhance

the

solar

cells

efficiency,

or

to

enh
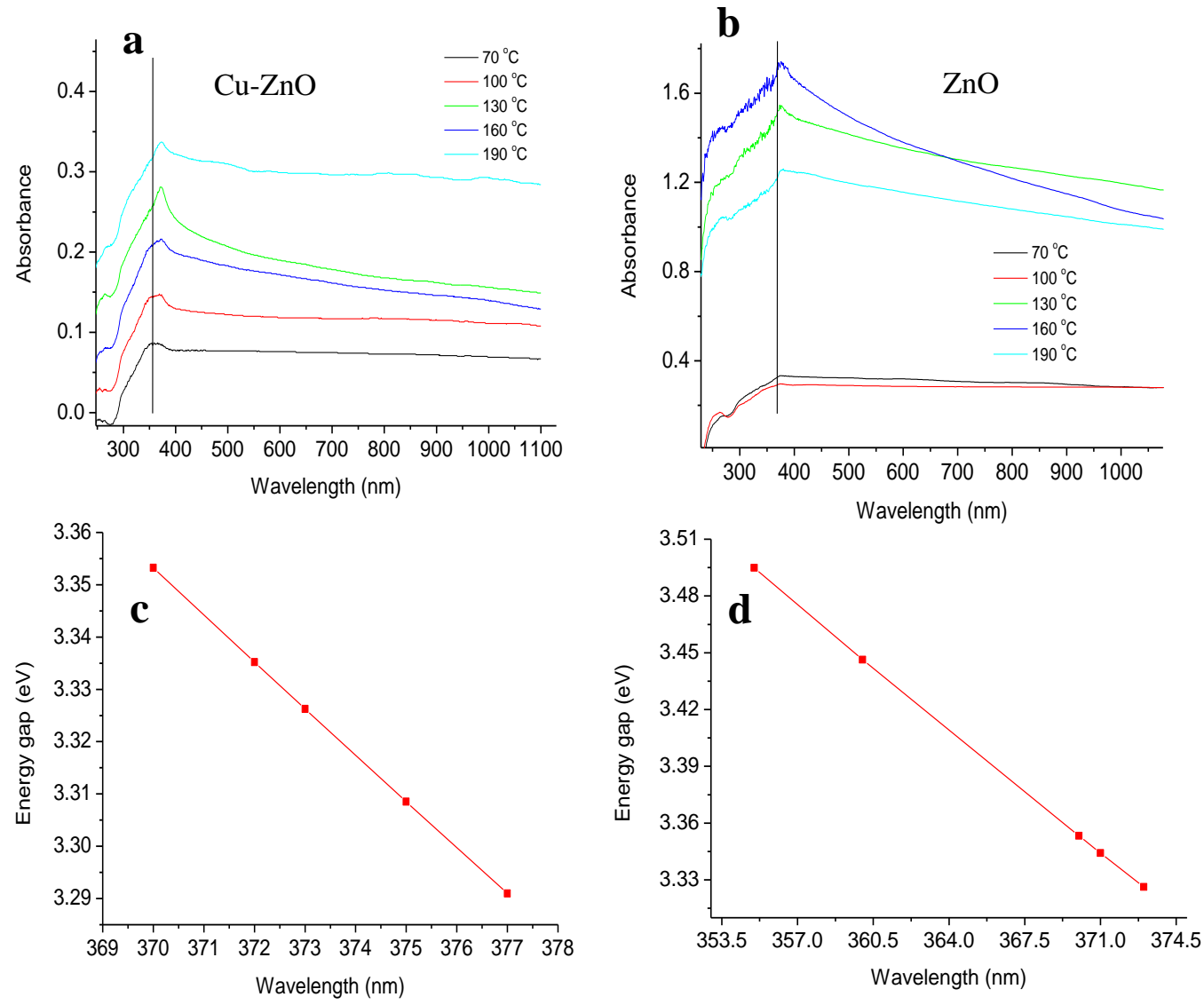

Figure 6-Top raw: UV-Vis spectra at the region of 225-1100 $\mathrm{nm}$ for (a) $\mathrm{Cu}-\mathrm{ZnO}$ nanostructures and (b) undoped $\mathrm{ZnO}$ nanostructures; both prepared at different temperatures of 70, 100, 130, 160 and 190 ${ }^{\circ} \mathrm{C}$. Bottom raw: the relationship between band gap energy values and the corresponding wavelength absorption peaks for (c) $\mathrm{Cu}-\mathrm{ZnO}$ nanostructures and (d) undoped $\mathrm{ZnO}$ nanostructures, taken from a and $b$.

ance the green luminescence which could be used for high bio-imaging performance, i.e. for highly sensitive detection of pathogens.

Table 2- Comparison of absorption peaks and band gap energy values for $\mathrm{Cu}-\mathrm{ZnO}$ and undoped $\mathrm{ZnO}$ nanostructures.

\begin{tabular}{|c|c|c|c|c|}
\hline \multirow{2}{*}{$\begin{array}{c}\text { Synthesis } \\
\text { Temperature }\left({ }^{\circ} \mathrm{C}\right)\end{array}$} & \multicolumn{2}{|c|}{$\mathrm{Cu}-\mathrm{ZnO}$} & \multicolumn{2}{c|}{ undoped ZnO } \\
\cline { 2 - 5 } & Wavelength (nm) & Energy gap (eV) & Wavelength (nm) & Energy gap (eV) \\
\hline 70 & 370 & 3.35324 & 355 & 3.49493 \\
\hline 100 & 372 & 3.33522 & 360 & 3.44639 \\
\hline 130 & 373 & 3.32627 & 370 & 3.35324 \\
\hline 160 & 375 & 3.30853 & 371 & 3.34421 \\
\hline 190 & 377 & 3.29098 & 373 & 3.32627 \\
\hline \hline
\end{tabular}

\section{Conclusions}

The hydrothermal technique was found to be a low-cost, and short- time based technique with low temperature requirements, which could be used to produce $\mathrm{Cu}-\mathrm{ZnO}$ nanostructures with appreciable amounts of pure and well configured crystallites. $5 \mathrm{wt} \%$ copper was found to be sufficient to reduce $\mathrm{ZnO}$ crystallite size and, interestingly, to modify $\mathrm{ZnO}$ crystallites into a new hexagonal configuration 
with three unprecedented extra planes which we believe that they are either outer planes, inner planes, or possibly both. The exact scenario of this configuration would be an attractive topic for future work. Maintaining higher temperature is a preferable routine to be followed in order to increase nanostructure size, due to Ostwald Ripening phenomenon.

\section{References}

1. Klingshirn, C. 2007. ZnO: material, physics and applications. Chemistry Europe,8(6): 782-803.

2. Abdulrahman, N. and Mohammed, H. 2017. Temperature and Solvent Impact on Zinc Oxide Nanostructures Synthesized via Hydro-Solvo-Thermal Technique. International Journal of Science and Research (IJSR), 6: 1132-1136.

3. Abdulrahman, N. and Haddad,N. 2020. Braggs, Scherre, Williamson-Hall and SSP analyses to estimate the variation of crystallites sizes and lattice constants for $\mathrm{ZnO}$ nanoparticles synthesized at different temperatures. NeuroQuantology, 18: 53-63.

4. Ghosh, S., Srivastava,P., Pandey, B., Saurav,M., Bharadwaj, P., Avasthi, D. Kabiraj,D. and Shivaprasad, S. 2008. Study of $\mathrm{ZnO}$ and $\mathrm{Ni}$-doped $\mathrm{ZnO}$ synthesized by atom beam sputtering technique. Springer, 90(4): 765-769.

5. Fierro, J. 2005. Metal oxides: chemistry and applications.: CRC press.

6. Hassan, N., Hashim, Al-Douri, M. and Al-Heuseen, K. 2012. Current dependence growth of ZnO nanostructures by electrochemical deposition technique. International Journal of Electrochemical Science, 7: 4625-4635.

7. Al-Douri, , Haider,A. Reshak, A. Bouhemadou, A. and Ameri M. 2016. Structural investigations through cobalt effect on $\mathrm{ZnO}$ nanostructures. Optik, 127(20): 10102-10107.

8. Al-Douri, Reshak, A., Ahmed, W. and Ghazai, A. 2014. Structural and optical investigations of In doped $\mathrm{ZnO}$ binary compound. Materials Express, 4(2): 159-164.

9. Ahmad, A., Alsaad, A., Al-Bataineh, Q. and Al-Naafa, M. 2018. Optical and structural investigations of dip-synthesized boron-doped $\mathrm{ZnO}$-seeded platforms for $\mathrm{ZnO}$ nanostructures. Applied Physics A, 124(6): 458.

10. Karpina, V., Lazorenko,V., Lashkarev,C., Dobrowolski,V., Kopylova, L., Baturin,V., Pustovoytov, S., Karpenko, A., Eremin, S. and Lytvyn,P. 2004. Zinc oxide-analogue of GaN with new perspective possibilities. Journal of Experimental and Industrial Crystallography, 39(11): 980-992.

11. Özgür, Ü., Alivov,Y., Lio, C., Teke, Reshchikov,A., Dogan, S., Avrutin, S. Cho and H. Morkoc, 2005. A comprehensive review of $\mathrm{ZnO}$ materials and devices. Journal of applied physics, 98(4): 11.

12. Naveed Ul Haq, A., Nadhman, A., Ullah, I., G. Mustafa., Yasinzai, M. and Khan, I. 2017. Synthesis approaches of zinc oxide nanoparticles: the dilemma of ecotoxicity. Journal of Nanomaterials, 2017.

13. Khanizadeh, B., Khosravi,M., Behnajady, M., Shamel A. and Vahid,B. 2020. Mg and La Codoped ZnO Nanoparticles Prepared by Sol-gel Method: Synthesis, Characterization and Photocatalytic Activity. Periodica Polytechnica Chemical Engineering, 64(1): 61-74.

14. Rashid, R., Hussain, D. and Mahmood, R. 2020. Water Treatment Ability of CuO-ZnO Nanocomposites Synthesized by Laser Ablation and Anodization Techniques. Journal of Southwest Jiaotong University, 55(1).

15. Liu, C., Yu,A., Peng, M., Song,M., Liu, W., Zhang Y. and Zhai, J. 2016. Improvement in the piezoelectric performance of a $\mathrm{ZnO}$ nanogenerator by a combination of chemical doping and interfacial modification. The Journal of Physical Chemistry C, 120(13): 6971-6977.

16. Kunene, K., Sabela, M., Kanchi, S. and Bisetty, K. 2020. High performance electrochemical biosensor for bisphenol a using screen printed electrodes modified with multiwalled carbon nanotubes functionalized with silver-doped zinc oxide. Waste and Biomass Valorization, 11(3): 1085-1096.

17. Haq, B., Ahmed,R., Shaari, A., Ali, N., Al-Douri Y. and Reshak,A. 2016.Comparative study of Fe doped $\mathrm{ZnO}$ based diluted and condensed magnetic semiconductors in wurtzite and zinc-blende structures by first-principles calculations. Materials Science in Semiconductor Processing, 43: 123-128. 
18. Li, Y., Gao,Z., Qin, W., Wen Q. and Jun, M. 2016. Nano size related piezoelectric efficiency in a large $\mathrm{ZnO}$ thin film, potential for self-powered medical device application. Biochem Anal Biochem, 5(243): 2161-1009.1000243.

19. Ahmed, S. 2017. Effects of annealing temperature and dopant concentration on the structure, optical, and magnetic properties of $\mathrm{Cu}$-doped $\mathrm{ZnO}$ nanopowders. Journal of Materials Science: Materials in Electronics, 28(4): 3733-3739.

20. Sarkar, D., Ghosh, and Chattopadhyay, K. 2017.Carbon doped $\mathrm{ZnO}$ thin film: Unusual nonlinear variation in bandgap and electrical characteristic. Applied Surface Science, 418: 252-257.

21. Kayani, Z., Iram, S., Rafi, R., Riaz S. and Naseem, S. et al., 2018. Effect of Cu doping on the structural, magnetic and optical properties of $\mathrm{ZnO}$ thin films. Applied Physics A, 124(7): 468.

22. Ghahramanifard, F., Rouhollahi, A. and Fazlolahzadeh ,O. 2018. Electrodeposition of Cu-doped ptype $\mathrm{ZnO}$ nanorods; effect of $\mathrm{Cu}$ doping on structural, optical and photoelectrocatalytic property of $\mathrm{ZnO}$ nanostructure. Superlattices and Microstructures, 114: 1-14.

23. Ran, F., Tanemura, M., Hayashi, Y. and Hihara,T. 2009. Effect of substrate temperature on the room-temperature ferromagnetism of $\mathrm{Cu}$-doped $\mathrm{ZnO}$ films. Journal of crystal growth, 311(17): 4270-4274.

24. Battez, A., Gonzalez,R., Viesca, J., Fernandez, J., Diazfernandez, J., MacHado, Chou, R., Riba, J. 2008. $\mathrm{CuO}, \mathrm{ZrO} 2$ and $\mathrm{ZnO}$ nanoparticles as antiwear additive in oil lubricants. ELSEVIER, 265(3-4): 422-428.

25. Mittal, M., Sharma, M. and Pandey O. 2014.UV-Visible light induced photocatalytic studies of $\mathrm{Cu}$ doped $\mathrm{ZnO}$ nanoparticles prepared by co-precipitation method. Solar Energy, 110: 386-397.

26. Xu, S., Lu,H., Zhang, Y., Wang, T., Geng, , Huang,Y., Ding, S. and Zhang, D. 2015. Bandgap narrowing and conductivity evolution of atomic-layer-deposited $\mathrm{ZnO}: 2015$. $\mathrm{Cu}$ thin films under rapid thermal annealing. Journal of Alloys and Compounds, 638: 133-135.

27. Ahn, K.-S., Deutsch, T., Yan, Y., Jiang, C., Perkins, C., Turner J. and Al-Jassim M. 2007. Synthesis of band-gap-reduced p-type $\mathrm{ZnO}$ films by $\mathrm{Cu}$ incorporation. Journal of Applied Physics, 102(2): 023517.

28. Tosun, M., Senol, and Arda, L. 2020. Effect of $\mathrm{Mn} / \mathrm{Cu}$ co-doping on the structural, optical and photocatalytic properties of ZnO nanorods. Journal of Molecular Structure, 2020: 128071.

29. Liu, J., et al., 2019. Rapid Hydrothermal Growth of ZnO Nanorods on a Magnetron Sputtered Thick $\mathrm{ZnO}$ Seed Layer. in Key Engineering Materials. Trans Tech Publ In Key Engineering Materials.

30. Kathalingam, A. and Kim,H. 2018. Fabrication of two-terminal devices using solution-synthesized $\mathrm{Cu}$-doped $\mathrm{ZnO}$ nanorods and their photosensing properties. Optical Materials Express, 8(9): 28322842.

31. Chakraborty, M., Mahapatra, P. and Thangavel, R. 2016. Structural, optical and electrochemical properties of $\mathrm{Al}$ and $\mathrm{Cu}$ co-doped $\mathrm{ZnO}$ nanorods synthesized by a hydrothermal method. Thin Solid Films. 612: 49-54.

32. Ostwald, W. 1886. Lehrbuch der allgemeinen Chemie. Vol. 2.: W. Engelmann. W. Engelmann.

33. Ostwald, W. 1897. Studien über die Bildung und Umwandlung fester Körper. Zeitschrift für physikalische Chemie, 22(1): 289-330.

34. Shabannia, R. 2016. Synthesis and characterization of $\mathrm{Cu}$-doped $\mathrm{ZnO}$ nanorods chemically grown on flexible substrate. Journal of Molecular Structure, 1118: 157-160.

35. Sajjad, M., and Qureshi,M. 2018. Structural and optical properties of pure and copper doped zinc oxide nanoparticles. Results in Physics, 9: 1301-1309.

36. Rahmati, A., Sirgani, A. , Molaei M. and Karimipour, M. 2014. Cu-doped $\mathrm{ZnO}$ nanoparticles synthesized by simple co-precipitation route. The European Physical Journal Plus, 129(11): 250.

37. Fernandes, D., et al., 2009. Synthesis and characterization of $\mathrm{ZnO}, \mathrm{CuO}$ and a mixed $\mathrm{Zn}$ and $\mathrm{Cu}$ oxide. Materials Chemistry and Physics, 115(1): 110-115.

38. Dabir, F., Esfahani H. and Khodadadi, Z. 2020. Study on microstructural and electro-optical properties of sol-gel derived pure and $\mathrm{Al} / \mathrm{Cu}$-doped $\mathrm{ZnO}$ thin films. Journal of Sol-Gel Science and Technology: 1-10. 